\title{
PENGEMBANGAN SERVICE CLIMATE ORGANISASI UNTUK MENINGKATKAN EMPLOYEE WORK PASSION
}

\author{
Marina Sulastiana, Anissa Lestari Kadiyono, dan Aulia Anisyah Fassa \\ Fakultas Psikologi - Universitas Padjadjaran \\ E-mail: marina.sulastiana@unpad.ac.id
}

\begin{abstract}
ABSTRAK, Peningkatan iklim pelayanan dibutuhkan untuk dapat memberikan jasa terbaik bagi pasien yang membutuhkan perawatan pada Rumah Sakit. Upaya untuk dapat bekerja dengan baik dan juga mencintai profesi mereka merupakan hal yang penting untuk ditumbuhkan. Penelitian ini ingin melihat bagaimana pengaruh service climate terhadap employee work passion pada perawat di rumah sakit. Pengumpulan data dilakukan dengan menyebarkan kuesioner service climate berdasarkan teori Schneider \& White (2004), dan kuesioner employee work passion yang merujuk pada model employee work passion yang dikembangkan oleh Zigarmi et al., (2011) kepada 41 orang perawat. Pengujian hipotesis dilakukan dengan teknik analisis regresi linear sederhana. Hasil dari penelitian ini menunjukan terdapat pengaruh yang signifikan antara service climate terhadap employee work passion pada perawat. Hal ini menunjukkan semakin positif service climate di rumah sakit, maka akan semakin tinggi employee work passion pada perawat. Service climate yang positif dan employee work passion yang tinggi pada perawat dapat mendorong perawat memunculkan perilaku kerja yang memuaskan, sehingga dapat tercapai pelayanan yang berkualitas. Untuk mempertahankan dan meningkatkan service climate di rumah sakit dilakukan intervensi berupa workshop dan group counseling yang diberikan kepada perawat maupun pihak manajemen.
\end{abstract}

Kata kunci: service climate; employee work passion; kualitas pelayanan; perawat; rumah sakit.

\section{DEVELOPMENT OF ORGANIZATIONAL SERVICE CLIMATE TO IMPROVE EMPLOYEE WORK PASSIONS}

\begin{abstract}
Improved service climate is needed to be able to provide the best services for patients who need treatment at the Hospital. Efforts to work well and also love their profession are important things to grow. This study wants to see how the influence of service climate on employee work passion on nurses in hospitals. Data collection was carried out by distributing service climate questionnaires based on Schneider \& White (2004) theory, and employee work passion questionnaire which refers to employee work passion model developed by Zigarmi et al. (2011) to 41 nurses. Hypothesis testing is done by simple linear regression analysis techniques. The results of this study indicate that there is a significant influence between service climate on employee work passion in nurses. This shows that the more positive the service climate in the hospital, the higher the employee work passion in the nurse. Positive service climate and high employee work passion in nurses can encourage nurses to produce satisfying work behaviors, so that quality services can be achieved. To maintain and improve service climate in the hospital, interventions took the form of workshops and group counseling given to nurses and management.
\end{abstract}

Key words: service climate; employee work passion; service quality; nurses; hospitals.

PENDAHULUAN

Jumlah rumah sakit dari tahun ke tahun mengalami peningkatan. Hal ini mencerminkan upaya pemerintah untuk meningkatkan pemberian pelayanan kesehatan bagi seluruh lapisan masyarakat. Hal ini membuat rumah sakit perlu meningkatkan pelayanannya guna memberikan performa yang terbaik. Pelayanan rumah sakit di era sekarang tidak terlepas dari perkembangan ekonomi masyarakat. Hal ini tercermin pada perubahan fungsi klasik rumah sakit yang pada awalnya hanya memberi pelayanan yang bersifat penyembuhan saja terhadap pasien melalui rawat inap dan rawat jalan bergeser ke pelayanan yang lebih komprehensif.

Peningkatan kualitas hidup yang berujung pada meningkatnya penduduk lansia di Indonesia mengakibatkan berbagai penyakit penuaan seperti: penurunan fungsi tulang, jantung, gangguan penglihatan dan berbagai penyakit usia lanjut lainnya pun mulai bermunculan. Hal ini menjadi peluang bagi industri kesehatan untuk mendirikan berbagai rumah sakit dengan kekhususannya masing-masing.
Perkembangan industri rumah sakit yang cukup pesat tentunyajuga berpengaruh terhadap keberlangsungan rumah sakit sehingga rumah sakit perlu mengevaluasi dan meningkatkan kualitas pelayanan yang diberikannya agar dapat bersaing dengan pertumbuhan lingkungan.

Perawat secara umum tentunya dituntut untuk menunjukkan berbagai perilaku yang menunjukkan kepedulian, keramahan, empati, dan bertanggung jawab terhadap pasien mereka, begitu pula dengan perawat di RSKB Halmahera Siaga. Para perawat di RSKB Halmahera Siaga dituntut untuk bisa menunjukkan helping behavior yang memuaskan pelanggan, terlebih lagi sebagai rumah sakit yang mengkhususkan dirinya di bidang bedah ortopedi, dimana sebagian besar pasien yang datang ke rumah sakit ini adalah pasien usia lanjut, sikap dan perilaku dari perawat harus menceminkan perilaku yang sesuai dengan standar pelayanan rumah sakit khusus bedah ortopedi.

Standar kerja yang harus dipenuhi perawat di RSKB Halmahera Siaga tentunya berbeda dengan perawat di rumah sakit umum ataupun rumah sakit dengan kekhususan lainnya. Asuhan keperawatan ortopedi diberikan secara 
komprehensif dengan menggunakan pendekatan proses keperawatan yang meliputi pengkajian, perencanaan, implementasi dan evaluasi keperawatan (Permenkes R N0. 10 tahun 2015)

Sebagian besar pasien yang datang ke RSKB Halmahera Siaga merupakan pasien lanjut usia, yang mana pasien-pasien ini memiliki karakteristik tersendiri, sehingga perawatan yang dberikan pun akan berbeda jika dibandinkan dengan pasien hinnya Dalm meeda jika dha part

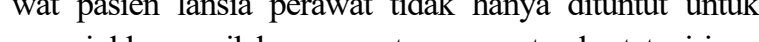
menujukkan perlaku perawat yang standar tetapi juga diharapkan dapat lebih aktif dan peka terhadap kondis pasien.

Perawat di bidang ortopedi perlu memerhatikan karakteristik yang dimiliki pasien ortopedi dan peka akan kebutuhan pasien. Pasien di bidang ortopedi akan rentan dengan berbagai situasi seperti nyeri, pendarahan, amputasi, latihan berjalan dengan berbagai alat bantu seperti tongkat dan walker, latihan kekuatan otot dan berbagai situasi lainnya. Keadaan-keadaan seperti ini tentunya akan menjadi hal yang sensitif bagi pasien, terutama pasien usia lanjut. Perubahan-perubahan yang akan terjadi pada dirinya saat pengobatan bukan hanya akan memberikan shock kepada pasien tetapi juga kepada keluarga pasien.

Hal ini pada akhirnya menuntut perawat ortopedi tidak hanya mampu melakukan berbagai tindakan asuhan keperawatan dengan baik, tetapi juga harus menunjukkan sikap yang positif dengan berbagai ekspresi emosi atau perasaan yang dapat mendorong dan memunculkan semangat di dalam diri pasien dan keluarga pasien. Perawat dituntut untuk menunjukkan sikap kerja yang positif. Karakteristik pasien yang berbeda ini mau tidak mau membutuhkan perawat yang memahami dan menghayati profesinya dengan baik dan positif.

Perawat-perawat di RSKB Halmahera Siaga menunjukkan perilaku kerja yang menggambarkan betapa jukkan pencinu keja you mecka per seon bahwa sebaglan best faktor yang menunjang pelayanan yang memuaskan di RSKB Halmahera Siaga terletak pada kinerja perawatnya yang berkualitas. Selain itu beberapa perawat juga menyatakan bahwa RSKB Halmahera Siaga memberikan berbagai fasilitas dan pendukung kerja yang membantu mereka menyelesaikan pekerjaan. Hal ini membuat mereka merasa dihargai sebagai seorang perawat. Dukungan-dukungan yang diberikan organisasi ini membuat para perawat memandang pekerjaannya sebagai sesuatu yang menyenangkan.

Data hasil wawancara menunjukkan bahwa perawatperawat di RSKB Halmahera Siaga terkenal dengan pelayanan yang ramah, bersahabat dan sangat mementingkan kualitas. Hal ini terlihat dengan adanya pasien RSKB Halmahera Siaga yang dirujuk ke RS lain tetap ingin dirawat oleh perawat dari RSKB Halmahera Siaga. Selain dirawat oleh perawat dari RSKB Halmahera Siaga. Selain
itu, hubungan yang terjalin antar perawat dengan sesama rekan kerja saling mendukung dalam proses penyelesaian pekerjaan, hangat, dan saling membantu jika ada yang memara perawat dengan atasa pun hangat dan menyenangkan. Selain itu prosedur kerja yang jelas, serta fasilitas yang disediakan rumah sakit sudah cukup memenuhi harapan para perawat. Antuasiasme kerja pun muncul di dalam diri para perawat di RSKB Halmahera Siaga

Kepala Divisi Penunjang Pelayanan menyatakan bahwa jika dipresentasikan, sekitar $80 \%$ perawat di RSKB Halmahera Siaga sudah menganggap profesinya sebagai perawat sebagai sebuah panggilan hati. Pekerjaan yang dilakukan memang sesuai dengan apa yang dibayangka perawat-perawat tersebut mengenai profesi merek sebagai seorang perawat.

Sikap kerja yang positif pada perawat di RSKB Halmahera Siaga yang ditunjukkan melalui bagainana penilaian yang positif di dalam diri mereka terhadap pekerjaan dan organisasi memunculkan kondisi emos yang positif di dalam diri mereka dalam menjalankan pekerjaan sebagai seorang perawat. Hal ini kemudian memunculkan sebuah keadaan kesejahteraan yang beras dari penilaian mereka terhadap kondisi pekerian do ran sebuah kecolo sebuah kecenderungan untuk menampilkan kinerja yan kerja tanpa diminta, dan kecenderungan untuk bertahan di kerja tanpa diminta, dan
RSKB Halmahera Siaga.

Sikap kerja perawat yang positif ini tentunya dipengaruhi juga oleh faktor-faktor pendukung yan berikan organisasi untuk penyampaian pelayanan yan berkualitas. Dari data awal yang di dapat, perawat d RSKB Halmahera Siaga memersepsi berbagai bentuk upaya yang dilakukan rumah sakit untuk memampukan mereka dalam memberikan pelayanan yang berkualitas, atau disebut juga service climate, dengan berbeda-beda Sebagian perawat memersepsi dengan positif service lim positif service climate RSKB Halmahera Siaga, tetapi sebagian belum memuaskan atau negatif.

Dari hasil observasi yang dilakukan peneliti, antara kepala bagian keperawatan dengan para perawat lainny terjadi komunikasi dua arah, dimana perawat pelaksan dapat dengan bebas mengekspresikan pendapatnya kepada atasan, sehingga penyampaian informasi dan koordinasi yang berjalan pun menjadi efektif. Selain itu, peningkatan kemampuan tenaga medis terkait pelayanan juga menjad perhatian manajemen dalam setiap penyusunan rencan kerja tiap tahunnya. Hasil wawancara menunjukkan bahwa penyediaan kesempatan untuk mengembangkan diri sepert training, dan seminar memang disediakan oleh pihak RSKB Halmahera Siaga, tetapi belum seluruh karyawan bisa mengikuti pelatihan ini.

Di samping itu, survey pelanggan yang dilakukan RSKB Halmahera Siaga setiap bulan membantu para perawat untuk mendapatkan informasi mengenai kualitas pelayanan yang ada di rumah sakit, khususnya pelayanan yang disampaikan oleh para perawat. Hasil dari feedback pelanggan ini pun berguna bagi perbaikan SPO ataupun saran untuk program kerja tahun berikutnya. Persepsipersepsi yang berkembang di dalam diri perawat ini berpengaruh terhadap penilaian mereka mengenai kondisi lingkungan pekerjaan mereka. Hal ini akan mempengaruhi penghayatan perawat terhadap profesi mereka.

Sebagai seorang perawat tentunya kondisi organisasi dan lingkungan kerja yang mereka rasakan akan sangat mempengaruhi sikap mereka dalam bekerja. Jika RSKB Halmahera Siaga menyediakan lingkungan kerja yang mendukung perawat dalam menyampaikan pelayanan yang berkualitas, maka akan mendorong mereka memunculkan sikap kerja yang positif, kondisi emosi yang positif dan adanya perasaan kesejahteraan dalam bekerja. Hal-hal positif ini akan muncul dalam sebuah employee work passion.

Penjabaran diatas menyatakan bahwa persepsi perawat terhadap kondisi service climate di RSKB Halmahera Siaga masih berbeda-beda. Hal ini pada akhirnya menyebabkan work passion yang dimiliki perawat juga berbeda-beda sehinges sikap kerja yang ditampilkan ja yang ditampilkan pen sikap kejja yang posite dan mendukung pencapaian kualitas pelayan, ala jlga yang menampilkan sikap kerja yang negatif, sehingga pelayanan yang diberikan pun tidak maksimal. Kondisi seperti ini berdampak pada pengalaman kualitas pelayanan yang dirasakan oleh pasien pun menjadi berbeda-beda dan tidak merata. Padahal untuk dapat bersaing dan menjawab tantangan serta perubahan lingkungan, khususnya perkembangan dunia kesehatan yang pesat, RSKB Halmahera Siaga harus meningkatkan dan memastikan bahwa pelayanan yang diberikan memuaskan pelanggan.

\section{Service Climate}

Service climate merupakan kajian lanjutan dari konsep besar organizational climate. Pada awal penelitian mengenai iklim, para peneliti melakukan pengukuran pada hampir semua hal yang ada di lingkungan sekitar pekerja. Sebuah survei mengenai iklim organisasi akan mempertanyakan mengenai persepsi pegawai tentang beberapa aspek dalam lingkungan kerja seperti pemimpin, sistem reward, training yang diterima pegawai dan lainlain. Konsep mengenai service climate pertama kali diperkenalkan oleh Schneider pada tahun 1980.

Konsep ini dilahirkan dari pemahaman mengenai pandangan pegawai terhadap aspek-aspek pada iklim organisasi yang terlalu luas dan ter kan untuk mendapatkan hasil yang spesifi. dikembangkan tidaklah fokus untuk diaplikasikan dalam perusahaan atau untuk mencari hubungan secara statistik antara iklim organisasi terhadap hasil spesifik yang diinginkan (Schneider \& White, 2004). Dengan kata lain, Schneider menyampaikan bahwa pengukuran terhadap iklim sebaiknya memiliki fokus yang spesifik. Penelitian mengenai iklim yang lebih spesifik ini contohnya adalah climate for safety, climate for employee well-being, ataupun climate for service.

Di dalam bukunya Service Quality Research Perspective, Schneider \& White (2004) mendefinisikan service climate sebagai persepsi yang berkembang $\mathrm{d}$ antara karyawan tentang kebijakan, aktivitas keria, do prosedur seta berbagi bentuk perilak yong mendap posen konsumen dan mencapai pelayanan konsumen yang berkualitas. Schneider \& White (2004) menyatakan bahwa apabila sebuah organisasi memiliki iklim yang kuat untuk pelayanan, akan terlihat dari kebijakan, praktik, dan prosedur yang ada mencerminkan bahwa layanan merupakan ha yang dianggap penting dalam organisasi tersebut.

Schneider \& White (2004) menyatakan bahwa apabila sebuah organisasi memiliki iklim yang kuat untuk pelayanan, akan terlihat dari kebijakan, praktik, dan prosedur yang ada mencerminkan bahwa layanan merupakan hal yang dianggap penting dalam organisas tersebut. Contohnya sebuah organisasi dengan service climate yang kuat secara formal akan mengevaluas bagaimana pegawinya memberikan pelayanan, dan ak memberikan kompensasi terhadap evaluasi yang dilakukan. Kebijakan-kebijakan tersebut akan membuat pegaw mengerti bahwa kualitas layanan merupakan hal yang enting dalam organisasi.

Menurut Lytle, Horn \& Mowka (dalam Tjiptono, 2005), service climate yang kuat terbentuk manaka pegawai menyepakati bahwa kualitas pelayanan benabenar difokuskan dalam organisasinya dan itu tercermi dalam perilaku manajemen. Karakteristik organisas yang memiliki service climate yang kuat meliputi: fokus kepemimpinan pada sasaran dan perencanaan pelayanan, recognition and reward bagi service climate, setio pemberian playann mendapattan duke chen internal pihak terkait tersediany a do per untuk melayanan, reka jasa yang disampaikan berkualitas tinggi.

Schneider dan Bowen (dalam Johnston, N., Sharma B., Spinks, W., (2013) juga menyampaikan bahwa servic climate dapat ditingkatkan dengan merekrut orang-orang yang memiliki keinginan dan mampu memberikan pelayanan yang terbaik. Mereka juga menyatakan bahwa peralatan, prosedur, dan teknologi sebaiknya disediaka dalam melayani pegawai dan pelanggan. Pada awal penelitiannya, Schneider et al. (1980, dalam Schneider \& White, 2004), menyusun tujuh dimensi service climate, yaitu (1) managerial functions, (2) effort rewarded, retain customer (4) personnel support, (5) central processing support (6) marketing support, dan (7) supply support. Kemuri menggabungkan ketujuh dimensi ini ke dalam empat komponen yang mendasar, yakni (1) branch management, 
(2) customer retention, (3) systems support, dan (4) logistic support. Kedua bentuk pembagian dimensi ini belum secara jelas menggambarkan suatu service climate. Akhirnya Schneider bersama koleganya White \& Pau kembali melakukan penelitian dengan menggunakan dua dimensi sebagai fondasi dan tiga dimensi berkaitan dengan service climate, yang disebut fondation issues.

Schneider \& White (2004) menjelaskan bahwa service climate bergantung pada faktor pendukung das dalam hal sumber daya, pelathan, praktik manajemen, dan pendukung linnya yang dibutukan pegwai

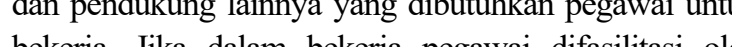

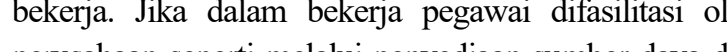
perusahaan seperti nelalti penyediaan sumber daya $\mathrm{d}$ pengawasan yang sume dapat memfokuskan dirinya pada upaya pemenuha

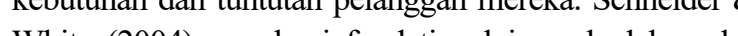
White (2004) membagi fondational issue kedalam dua hal yaitu 1) kualitas pelayanan internal dalam perusahaa (interdepartment service/internal service), yang merujuk pada kualitas pelayanan antar bagian atau divisi yan dipersepsi oleh masing-masing bagian atau divisi perusahaan, dan 2) kondisi fasilitas secara umum (work facilitation), yaitu upaya manajemen perusahaan untuk memfasilitasikerja pegawai dalam memberikan pelayanan menangani hambatan kerja, perilaku pengawasan, pemberian informasi, dan pembuatan kebijakan sumber day manusia.

Schneider \& White (2004) menjelaskan bahwa fondation issues merupakan faktor penting untuk memun-

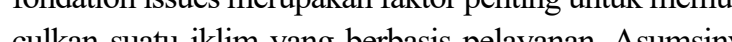
cilla adah kên mendapat dukungan dari pegawai lain yang melayani pegawai pember pelayanan tersebut. Kedua, Klim berbasis pelayanan ini dapat diciptakan jika organisasi itu memberikan praktk nanajenrn yang hendukung seperti pemberian program pelatihan untuk mengembangkan kompetensi yang dibutuhkan untuk melakukan pekerjaannya dengan baik. Setiap dimensi ini merupakan aset di lingkungan kerja yang menunjang pelayanan, seperti customer orientation, managerial practices, dan customer feedback.

\section{Employee Work Passion}

Meskipun passion tampak telah memiliki 2000 tahun sejarah intelektual, bidang psikologi masih belum menggambarkan aspek emosionalnya yang meliputi ketertarikan pribadi, komitmen, dan komitmen yang berlebih (over-commitment) hingga saat ini (Krapp, 2012, dalam Gaan \& Mohanty, 2014). Literatur yang ada menjelaskan konsep passion di dalam berbagai kegiatan diluar pekerjaan (non-work activity), seperti olah raga, romansa, penggunaan internet, dan pejudian (Amiot et al., 2006; Mageau et al., 2005; Rousseau et al., 2002; Segui Levesque et al., 2003; dalam Gaan \& Mohanty, 2014).

Sebagian besar pekerjaan kreatif merupakan out come dari passion, dipengaruhi baik dari keteratrikan dasar seseorang terhadap jenis pekerjaan tertentu dan juga lingkungan kerja yang mengelilingi individu tersebut Amabile, 2001; Fisher \& Smith, 2006; dalam Gaa Mohanty, 2014), dan dinyatakan menghasilkan outcome kognitif, afeksi, dan instrumental (Vallerand \& Houlfort, 2003; dalam Gaan \& Mohanty, 2012). Passionjuga menjad bahan dasar aktif untuk pertumbuhan perusahaan (Baum, Locke, \& Smith, 2001; dalam Gaan \& Mohanty, 2014) kesejahteran (Burke \& Fiskenbaum, 2009; dalm 2014), Mohanty 2014), diskenbaum, 2009; dalam Gaan \& Molanty, 2014), dan kesuskesan usaha (Cardon, Zietsma Sapartto, Mathene, Davis, 2005; dalam Gaan \& Mohanty, 2014). Zigarmi, Nimon, House, Witt, dan Diehl (2009, dalam Zigarmi et al., 2011) mengusulkan sebuah mode proses untuk memformulasikan employee work passion menggunakan teori sosial kognitif sebagai kerangk dasar. Menyadari isu mengenai literatur work engagement yang sudah ada, Zigarmi et al. mengembangkan sebua model kognitif yang memisahkan konstruk dari work affect, work cognition, dan work intention agar dapa menjelaskan formasi dari sebuah konstruk yang mereka namakan employee work passion.

Penggunaan istilah employee work passion bertujuan untuk membedakan konstruk dari redundansi, kebingungan, dan kesalahan interpretasi yang berhubungan dengan work engagement (Zigarmi et al., 2011). Teori ini dengan work engagement (Zigarmi et al., 2011). Teori ini melayani karyawan mereka berdasarkan pemahaman melayani karyawan mereka berdasarkan pemahaman
faktor-faktor yang berhubungan dengan pengalaman faktor-faktor yang berhubungan dengan pengalaman
karyawan terkait kehidupan pekerjaan organisasi mereka terhadap work passion yang mereka hasilkan (Zigarmi al., 2011)

Zigarmi et al. (2011) menyatakan employee work passion sebagai kegigihan individu, keadaan emosi yang positif, didasarkan pada sesuatu yang bermakna, kondisi kesejahteraan, yang berasal dari penilaian kognitif dan afektif yang berulang mengenai berbagai situasi pekerjaan dan organisasi yang menohasilkan perilaku dan inten kerja yang keja yang konsisten dan konstruktif. Employee work passion bukan hanya mengukur afek dan kognisi saja, tepi juga niat yang ada di dalam dirr individu, sehingg variabel ini menyediakan penjelasan yang lebih jela mengenai bagaimana individu berniat untuk berperilaku dalam kepentingan organisasi. Karyawan yang memiliki
work passion maka akan muncul intensi di dalam dirinya work passion maka akan muncul intensi di dalam dirinya yang selanjutnya akan memunculkan perilaku kerja yang konsisten dan membangun. Individu yang passionate terhadap pekerjaannya akan cenderung membantu rekan kerja, berbicara psoitif mengenai organisasi mereka, dan melakukan hal yang lebih dari apa yang diharuskan dalan pekerjaan mereka (Macey and Scneid

Employee work passion dipengaruhi oleh karakteristik organisasi dan pekerjaan yang dirasakan oleh karyawan. Karakteristik organisasi dan pekerjaan ini merujuk pada tiga konstruk yang mengacu pada 1) organizational experience (yaitu: meliputi harapan/ standar kinerja, procedural justice, distributive justice, dan growth), 2) job experience (yaitu meliputi kebermaknaan kerja, otonomi, keseimbangan beban kerja, dan varias tugas), dan 3) people experience (yaitu meliputi hubungan dengan atasan, hubungan dengan rekan kerja, umpan balik, dan kolaborasi/kerjasama. Employee work passion menggambarkan bagaimana sebuah passion terhadap pekerjaan yang dilakukan bisa terbentuk dalam diri individu melui proses penilaion (appraisal process) individu employee work passion, yaitu work cognition, work affect, employee work passion, yaitu work

Proses penilaian yang terjadi pada diri manusia bertujuan untuk menjelaskan bagaimana sebuah peristiwa dan pengalaman memengaruhi kesejahteraan (well-being) seseorang (appraiser). Manusia senantiasa menggambarkan sebuah peristiwa dari perspektif kesejahteraan (well-being) mereka yang dihubungkan dengan pengalaman mereka dengan lingkungan sekitar (masa lampau dan masa sekarang) dengan nilai-nilai individu, emosi, dan harapan untuk membentuk intensi dan perilaku di masa depan (Duffy \& Lent, 2009' Lent, 2004; Lent et al, 2005; dalam Zigarmi et 1 2011).

Pada tahap pertama proses penilaian (appraisal process), karyawan akan menilai dampak lingkungan kerja mereka terhadap kondisi kesejahteraan mereka sebagai seorang karyawan. Tahap ini melibatkan akumulasi penilaian karyawan terkait kondisi organisasi dan pekerjaan mereka yang dibentuk melalui interaksi dengan pengalaman kerja atau disebut juga dengan work cognition. Selain itu reaksi emosional karyawan yang dihasilkan dari persepsi terhadap kondisi pekerjaan dan organisasi tempat mereka bekerja, apakah emosi tersebut merupakan emosiemosi positif yang mendukung penyelesaian pekerjaan mereka, atau emosi-emosi negatif yang menghambat penyelesaian pekerjaan mereka, atau yang disebut juga dengan work affect, akan saling berhubungan dengan work cognition dit a

Kedua hal ini, work cognition dan work affect akan menjadi faktor dalam menentukan sense of job wellbeing karyawan, karena sebagai makhluk yang meaningoriented dan meaning-creating, manusia akan senantiasa mengevaluasi lingkungan dari sudut pandang well-being mereka dan bertindak secara rasional dan emosional berdasarkan evaluasi tersebut (Lazarus, 1991; Lazarus Folkman, 1984; dalam Ziagrmi et al., 2011). Sense of well-being ini berasal dari berbagai domain pengalaman seperti pekerjaan, hubungan sosial, dan keluarga. Pada model employee work passion, job well-being dilihat dari domain-domain yang berkaitan dengan pekerjaan (job).

Tahap kedua appraisal process adalah individu membuat penilaian untuk membentuk intensi sadar terkait bagaimana melakukan coping terhadap dampak lingkungan yang dihasilkan dari appraisal process tahap pertama. Tanpa tahap ini individu tidak bisa memilih alternatif atau tindakan untuk memunculkan intensi dan motivasi untuk membentuk masa depan. Intensi merujuk pada serangkaian representasi tujuan atau skema yang terbentuk sebagai sebuah hasil dari proses penilaian yang dirancang untuk memenuhi kebutuhan atau keinginan yang berasal dari perasaan mengenai terpenuhi atau tidaknya kondisi kesejahteraan (sense of well-being) individu.

Pada model employee work passion, intensi in disebut dengan work intention. Selama fase penilaian kedua, intensi dihasilkan untuk berhubungan dengan kesulitan yang berasal dari kebutuhan dan keinginan yang berhubungan dengan sense of well-being yang positif atau negatif. Oleh karena itu job well-being seorang karyawan akan menentukan dan memunculka sebuah work intention dalam bekerja. Hasil akhir dar proses penilaian ini lah yang kemudian membentuk sebuah work passion dalam diri karyawan.

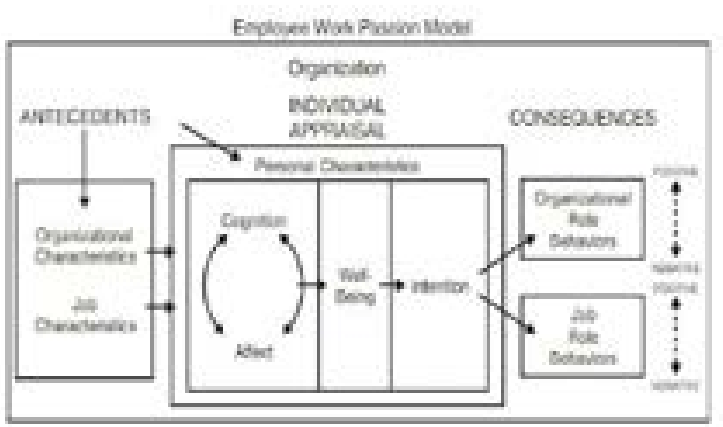

Sumber : Zigarmi et al., 201

Gambar 1. Model Konseptual dari Employee Work Passio

METODE

\section{Prosedur dan Partisipan}

Penelitian ini menggunakan desain penelitian kuantitatif deskriptif. Variabel diukur dengan menggunakan instrumen-instrumen penelitian, sehingga data yang d dapatkan berupa angka-angka yang pada akhirnya aka para angka-angka yang pada akhirnya aka then dengan menggunakan prosedur-prosedur pentitungan statistika guna mengetahui hubungan kausalitas antar variabel. Adapun hubungan kausalitas adala guna menjawab pertanyaan penelitian.

Populasi penelitian ini adalah perawat di RSKB Halmahera Siaga. Seluruh perawat di RSKB Halmahera Siaga ditetapkan sebagai populasi penelitian. Perawat di RSKB Halmahera Siaga tersebar kedalam empa instalasi pelayanan, yaitu IGD, Rawat Jalan, Rawat Inap, dan Kamar Bedah. Adapun gambaran jumlah populas berdasarkan masing-masing instalasi yang ditempati dijelaskan pada Tabel 1 .

Berdasarkan tabel 1. komposisi karyawan RSKB Halmahera Siaga maka didapatkan jumlah populas sebesar 41 orang.

Pengukuran

Pengukuran service climate dilakukan dengan menggunakan adaptasi kuesioner dari Sulastiana (2012). 
Kuesioner ini mengukur lima dimensi service climate yang berasal dari konsep teori service climate Schneider \& White (2004), yaitu work facilitation, internal service, customer orientation, managerial practices, dan customer feedback.

Pengukuran employee work passion dilakukan dengan menggunakan kuesioner yang dirancang sesuai dengan 4 dimensi employee work passion yang dikem kakan oleh Zigarmi et al., (2011), yaitu work cognition, work affect, job well-being, dan work intention.

Tabel 1. Komposisi Perawat di RSKB Halmahera Siaga

\begin{tabular}{lll}
\hline No. & Instalasi & Jumlah \\
\hline 1 & IGD & 8 Orang \\
2 & Rawat Jalan & 9 Orang \\
3 & Rawat Inap & 15 Orang \\
4 & Ruang Operasi & 9 Orang \\
\hline \multicolumn{2}{c}{ Total } & 41 orang \\
\hline
\end{tabular}

HASIL DAN PEMBAHASAN

Pengujian hipotesis penelitian dilakukan menggunakan metode analisis regresi linear sederhana. Hasil d analisis regresi yang dilakukan dijelaskan pada tabel Berikut penjelasan tabel 2 dan uraiannya.

Tabel 2. Hasil Uji Regresi Linear Sederhana

\begin{tabular}{lccccc}
\hline $\mathrm{IV}(\mathrm{X})$ & $\mathrm{DV}(\mathrm{Y})$ & t-hitung & $\mathrm{R}$ & $\begin{array}{l}\text { Pengaruh } \\
(\mathrm{R} \text { square })\end{array}$ & Sig. \\
\hline $\begin{array}{l}\text { Service } \\
\begin{array}{l}\text { Cli } \\
\text { mate }\end{array}\end{array}$ & $\begin{array}{l}\text { Wmployee } \\
\text { Work Pas- }\end{array}$ & 3,528 & 0,49 & $24,2 \%$ & 0,001 \\
\hline
\end{tabular}

Dari tabel 2. terlihat bahwa besar sig. atau p-value untuk analisis regresi adalah sebesar 0,001 . Nilai in berada dibawah standar p-value 0,05 . Hasil ini bermakna bahwa terdapat pengaruh service climate terhadap bahwa terdapat pengaruh service climate terhadap
employee work passion, maka berdasarkan hasil tersebut disimpulkan bahwa H1 diterima. Hasil analisis regresi yang telah dilakukan juga menunjukkan bahwa service yang telah dilakukan juga menunjukkan bahwa service
climate memiliki pengaruh sebesar $24,2 \%$ terhadap climate memiliki pengaruh sebesar $24,2 \%$ terhadap
employee work passion. Hal ini terlihat dari besarnya $75,8 \%$ lainnya dipengaruhi oleh variabel-variabel lain diluar variabel yang diteliti.

Dari hasil penelitian didapat data bahwa sebagian besar perawat RSKB Halmahera Siaga, yaitu 55\% (22 orang) mempersepsi service climate secara cukup positif. Sebanyak $41 \%$ (17 orang) mempersepsi service clima secara positif $2 \%$ (1 negar negalf, din scrice analisis data melui distibusi frokn bahwa sebagian besar perawat RSKB Halmahera Siag yaitu $68 \%$ (28 orang) memiliki work passion yang tingg. Sebanyak 20\% (8 orang) memiliki tingkat work passio sedang, $10 \%$ (4 orang) memiliki tingkat employee work passion sangat tinggi dan $2 \%$ ( 1 orang) rendah, dan tidak ada perawat yang memiliki tingkat work passion sangat rendah $(0 \%)$.

Kemudian jika dilihat dari perbandingan kategorisasi dari kelima dimensi service climate didapa data sebaran kategorisasi cukup beragam pada masingmasing dimensi service climate. Dari sebaran data masing-masing dimensi tersebut, 3 dimensi yaitu intern service, customer orientation, dan managerial proctics service, customer oriention, dan managerial practices memillki kategri yang paling tinggi. Sedangkan dimensi work facilitation dan customer feedback memilki kategori cukup positif sebagai katego tertinggi. Jika dilihat secara keseluruhan sebagian besa perawat memiliki persepsi sangat positif paling banyak pada dimensi customer orientation. Untuk kategor positif paling banyak juga berada pada dimensi customer orientation, sedangkan untuk kategori negatif paling banyak dimiliki oleh dimensi internal service.

Pada variabel employee work passion mayoritas sebaran kategorisasi pada masing-masing dimensiemployee work passion berada pada kategori tinggi. Jumlah perawa terbanyak yang berada pada kategorisasi tingoi berad pada dimensi work intention, yaitu sebanyak 29 orag disusul oleh dimensi job well being dan work 29 orang disusulect yan masing-masing sejumlah 25 orang, dan terakhir adala dimensi work cognition sejumlah 21 orang.Kategorisa berikutnya yang paling banyak dimiliki oleh perawa RSKB Halmahera Siaga adalah kategorisasi sedang, di mana dimensi yang paling tinggi pada kategorisasi sedang diwakili oleh dimensi work cognition, yaitu sebanyak 21 orang, kemudian disusul oleh dimensi job well-being sejumlah 13 orang, work intention yaitu sejumlah 11 orang, dan work affect sejumlah 5 orang.

Untuk kategorisasi sangat tinggi dimensi work affect menempati peringkat teratas sejumlah 9 orang, disusul oleh dimensi job well-being sejumlah 3 orang, dan dimens work cognition sebanyak 1 orang. Sedangkan untuk mensi yang berada pad kategorisasi sangat tinggi. Kategorisasi rendah paling banyak diwakili oleh dimensi work cognition sebanyak orang, dan work intention sebanyak 1 orang. Sedangka dua dimensi lainnya, yaitu work affect dan job well-being tidak memiliki perawat yang berada pada kategorisas rendah.

Selain menghitung analisis regresi antar variabel service climate dengan employee work passion, penelitian ini juga menghitung perbandingan skor mean dari masingmasing dimensi di setiap variabel untuk melihat dimens mana yang memiliki dampak paling positif terhadap kemunculan masing-masing variabel. Hasil perhitungan uij beda skor mean masing-masing dimensi service climate dengan uji anova menjuk nilai $\mathrm{p}$-viveclimate dengan uji 0,01 , yang bern $\mathrm{p}<0,05$, sehngga skor mean kelim yang berbeda dari mean dimensi memiliki makna dan yang berbeda dari mean dimensi memiliki makna dan
bisa dibandingkan, sehingga jika dilihat dari skor mean nya didapat data bahwa dimensi customer orientation merupakan dimensi yang paling positif sumbanganny terhadap variabel service climate di RSKB Halmahera Siaga (mean : 3,73), disusul oleh dimensi work facilitation (mean : 3,36), customer feedback (3,30), internal service $(3,23)$ dan yang terakhir adalah dimensi managerial practices $(3,20)$.

Sedangkan uji beda skor mean menggunakan uji anova untuk variabel employee work passion menunjukkan $p$-value adalah 0,33 , yang berarti $\mathrm{p}<0,05$, sehingga keempat skor mean dimensi employee work passion memiliki perbedaan. Artinya skor yang berbeda passion memiliki perbedaan. Artinya skor yang berbeda
dari mean dimensi employee work passion bermakna dan bisa dibandingkan, sehingga jika dilihat dari skor mean-nya didapat data bahwa dimensi job well-being merupakan dimensi yang paling positif sumbangannya terhadap variabel employee work passion di RSKB Halmahera Siaga, disusul oleh dimensi work intention, work cognition, dan yang terakhir adalah work affect.

Hasilpenelitianinimemperlihatkanadanya pengaruh signifikan yang diberikan service climate terhadap tinggi rendahnya employee work passion pada perawat RSKB Halmahera Siga Hal ini menjelaskan bawa service climate yang culk posif di RSKB Hahwa service climare yag che Hal yang dganbanan diantara perawat di RSKB Halmahera Siaga mengenai bagaimana manajemen, prosedur, kebijakan, dan perilakuperilaku yang dinargai atau didukng RSKB Halmahera Siaga terkait pelayanan yang berkualitas kepada pasien mendukung munculnya employee work passion yang tinggi pada perawat di RSKB Halmahera Siaga.

Service climate yang cukup positif ini artinya adalah secara keseluruhan perawat memersepsi berbagai bentuk upaya, tindakan dan kebijakan yang dilakukan RSKB Halmahera Siaga dalam mendukung pemberian pelayanan yang berkualitas sudah dilakukan dengan cukup baik, sehingoa mereka merasa pekerjaan merk sebagai perawat cukup mendapat dukungan dan perhatian dari rumah sakit.

Sesuai dengan model employee work passion dari Zigarmi et al., (2011), munculnya employee work passion didukung oleh karakteristik dari organisasi dan pekerjaan perawat yang tergambar melalui persepsi mereka terhadap apa yang mereka alami dan rasakan selama bekerja di RSKB Halmahera Siaga, seperti standar kinerja, kesempatan untuk berkembang, hubungan dengan rekan kerja maupun atasan, feedback terhadap kinerja serta kerjasama yang terbangun antar sesama rekan kerja (Egan, 2015). Karakteristik organisasi dan pekerjaan ini tergambar dari dimensi-dimensi yang dimiliki oleh service climate, yaitu: work facilitation, internal service, managerial practices, customer feedback, dan customer orientation.

\section{SIMPULAN}

Hasil penelitian menunjukkan secara keseluruhan perawat RSKB Halmahera Siaga menilai service climate dengan cukup positif. Hal ini menunjukkan bahwa perawat merasa bahwa RSKB Halmahera Siaga melakukan berbagai upaya untuk membantu dan mendukung merek dalam memberikan pelayanan yang berkualitas kepada pasien dengan cukup baik. Selain itu, perawat di RSKB Halmahera memiliki employee work passion yang tinggi. Hal ini menunjukkan bahwa secara keseluruhan perawa di RSKB Halmahera Siaga menunjukkan sikap kerja yang positif yang tergambar dalam kegighan kerja, keadan ensi, dan kondis kesejahteran yang posit terhadap pekerjan mereka sebagi seorng perawat Ha ini didasarkan pada penilaian mereka terhadap berbaga situasi pekerjaan dan organisasi yang pada akhirnya menghasilkan perilaku dan intensi kerja yang konsisten dan konstruktif.

Dari hasil penelitian dirancang program intervens yang bertujuan untuk meningkatkan service climate RSKB Halmahera Siaga dalam rangka mempertahanka dan meningkatkan employee work passion pada perawat, sehingga dapat tercipta pelayanan yang berkualitas. Rangkaian program intervensi ini terdiri dari dua buah program. Program pertama adalah workshop yang diber nama "Creating Positive Service Climate for Better Halmahera" dan program "Gang adalah group counseling yang dibri "Group Counseling for Nurse in ncing Better Service"

Rancangan intervensi yang diajukan diharapkan dapat digunakan oleh pihak manajemen SDM RSKB Halmahera Siaga dalam rangka meningkatkan service climate guna mempertahankan dan meningkatkan employee work passion perawat. Selain itu, gambara service climate dalam penelitian ini dapat menjad masukan bagi pihak manajemen RSKB Halmahe Siaga dalam memperbaiki kondisi kebijakan, prosedur, dan berbagai upaya yang dilakukan organsiasi untuk memampukan karyawan mereka dalam menyampaikan pelayanan yang berkualitas kepada pasien. Gambara employee work passion dari hasil penelitian juga dapat digunakan sebagai salah satu acuan pihak manajemen dalam menentukan rencana jangka panjang perusahaan sekaligus sebagai acuan dalam menetapkan program kerja yang akan dilakukan, khususnya di bidang keperawatan.

\section{DAFTAR PUSTAKA}

Astakhova, M. N. (2015). The curvilinear relationship between work passion and organizationa citizenship behavior. Journal of Business Ethics, 130(2), 361-374.

Bowen, D. E., \& Schneider, B. (2014). A service climate synthesis and future research agenda. Journal of Service Research, 17(1), 5-22.

Chang, R. Y. (2002). The passion plan at work: Building passion-driven organization. John Wiley \& Sons.

DuBrin, A. J. (2010). Principles of leadership. 
Egan, R. (2015). Employee Work Passion: Leadership Behaviour, Employee Affect and Work Intentions (Doctoral dissertation, University of Canberra).

Fathiyah, W. (2015). Indeks Pembangunan Manusia Indonesia Alami Kemajuan. Diakses pada tanggal 22 Juli 2016 dari http://www.voaindonesia.com/a/ undp-indeks-pembangunan-manusia-indonesiaalami-kemajuan/3110936.html.

Gaan, N., \& Mohanty, K. (2014). Three-Factor Model of employee passion: An empirical study in the Indian context. Vikalpa, 39(2), 57-68.

Hidayat, A. (2015). Tiga Tahun Peringkat Indeks Pembangunan Manusia Indonesia Stagnan. Diakses pada tanggal 14 Juli 2016 dari https://m. tempo.co/read/news/2015/12/16/087728031/tigatahun-peringkat-indeks-pembangunan-manusiaindonesia-stagnan.

Johnston, N., Sharma, B., \& Spinks, W. (2013). Organisational climate, service climate and customer satisfaction: An investigation of their relationships in franchised hospitality enterprises. e-Journal of Social \& Behavioural Research in Business, 4(2), 34.

Keputusan Kemenkes RI No.983/Men.Kes/SK/XI/1992.

Lala, S. S. (2011). Pengaruh Service Climate terhadap Kualitas Pelayanan Karyawan Front-Line (Analisis pada Karyawan Front-Line Kantor Pos bandung sebagai Upaya Meningkatkan Kualitas PelayanannKaryawan Front-Line). Thesis, Universitas Padjadjaran.

Nampultig, K. (2012). Osteoporosis Membahayakan Organ Asia. Diakses pada tanggal 2 Januari 2016 dari http://osteoporosista.blogspot.co.id/2012/06/ osteoporosis-membahayakan-orang-asia.html.

Permenkes RINo. 10 tahun 2015. Pelayanan Keperawatan Ortopedi.
Prakarsa, (2015). Monitoring Pelaksanaan Layanan Badan Penyelenggara Jaminan Sosial BPJS Di Indonesia dan Penguatan Perencanaan dan Penganggaran Kesehatan Pada Tingkat Provinsi dan Kabupaten Kota. Diakses pada tanggal 20 Juli 2016 dari http://theprakarsa.org/new/in/ workshop/detail/29/Monitoring-PelaksanaanLayanan-Badan-Penyelenggara-Jaminan-SosialBPJS-Di-Indonesia-dan-Penguatan-Perencanaandan-Penganggaran-Kesehatan-Pada-TingkatProvinsi-dan-KabupatenKota.

Rencana Strategis Kementerian Kesehatan Tahun 20152019.

Rumah sakit ortopedi di Indoensia. Diakses pada tanggal 1 Januari 2016 dari http://rumah-sakit.findthebest. co.id.

Schneider, B., \& White, S. S. (2004). Service quality:

Research perspectives (Vol. 107). Sage.

Sulastiana, M. (2012). Studi mengenai Nilai-nilai Personal dan Servant Leadership pada aparat Desa dan pengelola Pariwisata di Pangalengan. Disertasi, Fakultas Psikologi Universitas Padjadjaran.

Syams, Ade. (2015). Perkembangan Penyakit Osteoporosis. Diakses pada tanggal 7 Januari 2016 dari http://adesyams.blogspot.co.id/2009/10/ perkembangan-penyakit-osteoporosis-di.html.

Vallerand, R. J. (2012). The role of passion in sustainable psychological well-being. Psychology of wellBeing: Theory, research and practice, 2(1), 1.

Vallerand, R. J. (2015). The psychology of passion: A dualistic model. Series in Positive Psychology.

Zigarmi, D., Nimon, K., Houson, D., Witt, D., \& Diehl, J. (2011). A preliminary field test of an employee work passion model. Human Resource Development Quarterly, 22(2), 195-221. 